\title{
Environmental Impact on the Stability of Gene Action for Seed Cotton Yield in Cotton (Gossypium hirsutum L.)
}

\author{
A.E. Patil", D.B. Deosarkar and M.R. Puttawar \\ Department of Agricultural Botany, College of Agriculture, VNMKV, \\ Parbhani, 431402, Maharashtra, India \\ *Corresponding author
}

\section{A B S T R A C T}

Hybrids are widely accepted in all crops to improve yield, but genotype $\times$ environment interaction plays an important role in achieving high yield and superior quality traits. Six

\section{Keywords}

Genotype $\times$

environment,

Combining ability,

Gene action

Article Info

Accepted:

12 December 2017

Available Online:

10 January 2018 lines and seven testers of Gossypium hirsutum L. varying in seed cotton yield and fiber traits were assessed for hybrid vigor using a line $\times$ tester system across three different locations. The objective of this study was to detect influence of genotype $\mathrm{x}$ environment interaction on stability of gene action. The level of heterosis was acceptable for seedcotton yield and fiber traits. Combining-ability analysis across environments showed significant $(\mathrm{P}<0.01)$ effects for genotypes, GCA, SCA, genotype $\times$ environment, GCA $\times$ environment, and SCA $\times$ environment interactions. Combining-ability variance revealed predominance of non-additive gene effects for seed cotton yield, ginning outturn, fibre parameters, earliness parameters, additive gene effects for plant height, seed index, lint index and equal contribution of additive and non-additive gene effects for sympodial branches and boll weight. A positive relationship was found between GCA effects and mean performance of parents, heterobeltiosis and SCA whereas negative relationship was observed between heterobeltiosis and better parent mean as the environmental quality increased.

\section{Introduction}

The increase in cotton production was attributable to exploitation of heterosis (hybrids) and selection of best combining parents. Heterosis has been exploited in crops such as cotton, maize, sorghum and pearl millet to improve yield and bring about early maturity. A hybrid-breeding program depends on suitable parents with sufficient level of heterosis. The evaluation of parental lines for performance in $\mathrm{F}_{1}$ hybrids can be estimated by evaluating combining ability. One of the methods used to select the parental material for hybrid breeding is line $\times$ tester analysis (Kempthorne 1957). This mating design provides information about GCA of parents, SCA of crosses, and other essential genetic parameters. The environment, consisting of different seasons, locations, and management practices, plays an important role in phenotypic expression of traits (Perkins et al., 1984; Rashmi et al., 2000). The genotypes showing the least genotype $\times$ environment 
interaction are considered desirable for breeding because of their wider adaptability and stability. Combining ability studies from a single environment may not provide precise information on gene action, as the environmental effects influence combining ability estimates (Dwivedi et al., 1999). Many researchers have studied the combining ability and genetic structure of cotton hybrid by using line $\times$ tester method related to yield and yield components. However, most of our present information about combining ability in cotton was based on studies carried under single environment. The effect of genotype and environment on phenotype may not always be independent since genotype $\times$ environment interaction has a masking effect on phenotype. The homozygosity or heterozygosity of genotypes also respond differently to the same environment (Cole et al., 2009).To detect the role of the environmental component on the heterosis and combining ability estimates of homozygous and heterozygous genotypes, studies should be carried out across a range of environments for unbiased information. Taking into account all of these factors, this study was aimed at to estimate association of environment with heterosis, combining ability for fiber traits and seed-cotton yield and to study influence of environmental factors on gene action.

\section{Materials and Methods}

\section{Experimental material}

The experimental material consisted of nine testers viz. PH 1060, LRA 5166, NH 635, PH 1075, PH 348, AK 32, NH 630, PH 1024, AKH 07 and seven lines viz. DHY 286-1, PH 93, IS 181-4-1, PH 93, NH 615, MCU 5 and $\mathrm{BN}$ 1. These lines and testers were crossed in a line $\times$ tester mating design (Kempthorne, 1957) during kharif 2013. The parents and their resulting $63 \mathrm{~F}_{1} \mathrm{~s}$ along with two hybrid checks were grown in a randomized complete- block design with two replicates at three locations during the 2014 growing season. The three locations in Maharashtra were Nanded $\left(19.1500^{\circ}\right.$ latitude, $77.3000^{\circ} \mathrm{E}$ longitude), Parbhani $\left(19.5000^{\circ} \mathrm{N}\right.$ latitude, $76.7500^{\circ} \mathrm{E}$ longitude), and Badnapur (19.8667 ${ }^{\circ} \mathrm{N}$ latitude, $75.8333^{\circ} \mathrm{E}$ longitude). Each genotype was sown in two-row plots of $6 \mathrm{~m}$ length with a spacing of $60 \mathrm{~cm}$ within rows and $90 \mathrm{~cm}$ between rows. Plots were managed conventionally following the established normal practices. Data were recorded on plot basis. Traits measured were days to first flowering, days to $50 \%$ flowering, plant height $(\mathrm{cm})$, number of monopodia per plant, internode length $(\mathrm{cm})$, node number per plant, days to first boll bursting, days to $50 \%$ boll bursting, earliness index, number of sympodia per plant, number of bolls per plant, boll weight $(\mathrm{g})$, yield per plant $(\mathrm{g})$ and seed cotton yield per hactare $(\mathrm{kg})$, seed index $(\mathrm{g})$, lint index, harvest index (\%), ginning percentage, UHML $(\mathrm{mm})$, uniformity index, micronaire value $(\mu \mathrm{g} / \mathrm{inch})$, fibre strength $(\mathrm{g} / \mathrm{tex})$ and fibre maturity coefficient (\%). Lint sample was analyzed in high volume instrument (HVI) on USDA mode to determine fiber-quality parameters.

\section{Statistical analysis}

Plot means were used for statistical analysis. The data were subjected to analysis of variance (ANOVA) for pooled as well as for individual environments. Genetic analyses were performed via a pooled line $\times$ tester method, as suggested by Eli-itriby et al., (1981).

The model used for analysis was

$x i j k r=\mu+1 i+t j+1 t i j+s k+1 s i k+t s j k+$ ltsijk + eijkr

where, xijkr is mean trait value for cross $\mathrm{i} \times \mathrm{j}$ in kth environment and rth replication; $\mu$ is the 
population mean effect; $l i$ is the GCA effect of the ith line; $t j$ is the GCA effect of the $j$ th tester; ltij is the SCA effect of cross $\mathrm{i} \times \mathrm{j}$; sk is the effect of the kth environment; lsik is the kth environment interaction effect of ith line; tsjk is the kth environment interaction effect of jth line; ltsijk is the kth environment interaction effect of cross $\mathrm{i} \times \mathrm{j}$; and eijkr is the random error effect associated with ijkrth observation. Correlations were calculated between female. Heterosis was calculated as per the method suggested by Fonseca and Patterson.

\section{Results and Discussion}

For seed cotton yield plant ${ }^{-1}$, highest standard heterosis over NHH 206 and NHH 44 was found in DHY 286-1 X PH 348 (38.55\% and $61.22 \%$ respectively) followed by DHY 286$1 \mathrm{X} \mathrm{NH} 635$ (29.23\% and $50.37 \%)$, DHY 286-1-1 X PH 1075 (18.66 \% and 37.98\%), NH 615X PH 348 (17.26 \% and $36.30 \%), \mathrm{NH}$ 615X PH 1075 (16.98\% and $36.12 \%)$ and NH 615 X NH 635 (13.85\% and $32.45 \%)$. Across the environments, highest better parent heterosis was found in DHY 286-1 X PH 348 (135.11\%) followed by DHY 286-1 X NH 635 (128.51 \%), DHY 286-1 X PH 1075 (102. $76 \%)$, NH 615X PH-1075 (95.23\%), NH 615 $\mathrm{X}$ PH 348 (93.75\%) and NH 615 X NH 635 (90.19 \%). Parents DHY 286-1 (17.37), NH 615 (14.83), NH 635 (21.30), PH 1075 (13.84) and $\mathrm{PH} 348$ (12.15) had positive and significant GCA to improve seed cotton yield plant $^{-1}$. The crosses DHY $286-1$ X PH 348 (34.45), NH 615 X PH 348 (19.15), DHY 286$1 \mathrm{X}$ NH 635 (17.54), NH 615 X PH 1075 (17.34), DHY 286-1 X PH 1075 (16.17) and NH 615 x NH 635 (7.31) exhibited significant SCA effects for seed cotton yield ${ }^{-1}$. Genotype and genotype $\times$ environment interaction effects were highly significant $(\mathrm{P}<0.01)$ in the analysis of variance for all the traits. The combining ability analysis of line $\times$ tester data across environments showed highly significant effects $(\mathrm{P}<0.01)$ for lines, testers and environment $\mathrm{X}$ crosses. The environment $\mathrm{X}$ crosses interaction, environment $\mathrm{x}$ line effect, environment $\mathrm{x}$ tester interaction effects and environment $\mathrm{x}$ line $\mathrm{x}$ tester interaction effects for important characters are presented in table 1. The ratio of GCA/SCA mean square i.e. predictability ratio for plant height, monopodial branches, seed index, lint index was greater than unity indicating the predominantly additive gene action in the expression of the character. This ratio for sympodial branches, boll weight was also very close to unity indicating the adequacy of additive gene action whereas the rest of the character possessed lesser predictability ratio than unity indicating the non-additive gene action as the prime cause in the expression of these traits.

The heterosis observed for the hybrids was significant and negatively associated with mean environment yield where high heterosis was observed in low yielding environments $\left[\mathrm{E}_{3}-\right.$ Badnapur; $\mu$ (population mean) $=46.78 \mathrm{~g}$ plant $\left.^{-1}\right]$ than moderate yielding $\left(\mathrm{E}_{2}\right.$ - Parbhani; and high yielding environments $\left(\mathrm{E}_{1}\right.$ - Nanded; $\mu=51.23 \mathrm{~g} \mathrm{plant}^{-1}$ ). Plotting the better parent heterosis for crosses over three types of environments that represent low, moderate and high yielding areas revealed an obvious decline in heterosis as mean yield of parents increased in favourable environments. The trend of heterobeltiosis over locations for seed cotton yield plant $^{-1}$ is graphically represented in figure 1 . The low yielding environment $\left(E_{3}\right)$ had a significantly higher better parent heterosis than moderate and high yielding environments indicating more stable nature of heterozygous crosses than homozygous parents.

The performance of these parents and crosses for combining ability in relation to yield is presented in figure 2 . They have significantly interacted with environment. 
Table.1 Pooled Analysis of variance of important characters across different environments

\begin{tabular}{|c|c|c|c|c|c|c|c|}
\hline \multirow[t]{2}{*}{ Source of variation } & \multirow[t]{2}{*}{ d.f. } & \multicolumn{6}{|c|}{ Mean sum of squares } \\
\hline & & $\begin{array}{c}\text { Days to first } \\
\text { flower } \\
\text { initiation }\end{array}$ & $\begin{array}{l}\text { Days to } 50 \\
\% \text { flowering }\end{array}$ & $\begin{array}{l}\text { Plant height } \\
\text { (cm) }\end{array}$ & $\begin{array}{c}\text { No. of } \\
\text { monopodia } \\
\left(\text { plant }^{-1}\right)\end{array}$ & $\begin{array}{l}\text { Internode } \\
\text { length }(\mathrm{cm})\end{array}$ & $\begin{array}{c}\text { Node } \\
\text { number } \\
\left(\text { plant }^{-1}\right)\end{array}$ \\
\hline Replications & 1 & 2.71 & 0.01 & 5.78 & 0.001 & 0.08 & 2.47 \\
\hline Crosses & 62 & $63.81 * *$ & $71.89 * *$ & $909.84 * *$ & $3.56 * *$ & $2.03 * *$ & $42.44 * *$ \\
\hline Line effect & 6 & $150.06^{* *}$ & $205.04 * *$ & $1539.05^{* *}$ & $23.50 * *$ & $3.03 * *$ & $106.57 * *$ \\
\hline Tester effect & 8 & $109.80 *$ & $145.18 * *$ & $4011.18 * *$ & $3.00 * *$ & $5.93 * *$ & $130.97 * *$ \\
\hline Environment $*$ Tester effect & 16 & 5.20 & 9.06 & $27.87 *$ & 0.16 & 0.16 & 5.15 \\
\hline $\begin{array}{l}\text { Environment } * \text { Line } * \text { Tester } \\
\text { effect }\end{array}$ & 96 & 3.73 & $5.89 *$ & 14.26 & $0.17 * *$ & 0.12 & $3.86^{*}$ \\
\hline Error & 186 & 4.74 & 4.08 & 18.27 & 0.07 & 0.14 & 2.71 \\
\hline$\sigma^{2}$ gca & & 2.608 & 3.5631 & 57.4342 & 0.2747 & 0.0904 & 2.418 \\
\hline$\sigma^{2} \operatorname{sea}$ & & 6.77 & 6.4934 & 49.338 & 0.1816 & 0.1855 & 2.8259 \\
\hline$\sigma^{2}$ gca/ $\sigma^{2}$ sca & & 0.39 & 0.55 & 1.16 & 1.51 & 0.49 & 0.86 \\
\hline
\end{tabular}

***. Significant at $5 \%$ and $1 \%$ level respectively 
Table. 1 continued

\begin{tabular}{|c|c|c|c|c|c|c|c|}
\hline \multirow[t]{2}{*}{ Source of variation } & \multirow[t]{2}{*}{ d.f. } & \multicolumn{6}{|c|}{ Mean sum of squares } \\
\hline & & $\begin{array}{l}\text { Days to first } \\
\text { boll burst }\end{array}$ & $\begin{array}{l}\text { Days to } 50 \% \\
\text { boll burst }\end{array}$ & $\begin{array}{l}\text { Earliness } \\
\text { index }\end{array}$ & $\begin{array}{c}\text { No. of } \\
\text { sympodia }^{\left(\text {plant }^{-1}\right)}\end{array}$ & $\begin{array}{c}\text { Number of } \\
\text { bolls (plant }{ }^{-1} \text { ) }\end{array}$ & $\begin{array}{c}\text { Boll } \\
\text { weight } \\
\text { (g) }\end{array}$ \\
\hline Replications & 1 & $54.86 * *$ & 3.62 & 0.0008 & 0.12 & 31.77 & $0.19 * *$ \\
\hline Environments & 2 & $121.09 * *$ & $177.60 * *$ & $0.0715 * *$ & $304.50 * *$ & $370.75 * *$ & $2.80 * *$ \\
\hline Replication * Environments & 2 & 2.57 & 5.60 & 0.0013 & 1.13 & 6.94 & 0.01 \\
\hline Crosses & 62 & $40.74 * *$ & $83.92 * *$ & $0.0090 * *$ & $66.17 * *$ & $262.95 * *$ & $0.88 * *$ \\
\hline Line effect & 6 & 39.13 & $211.39 * *$ & $0.0224 * *$ & $193.47 * *$ & $1032.96 * *$ & $1.21 * *$ \\
\hline Tester effect & 8 & $102.19 * *$ & $137.67 * *$ & $0.0198 * *$ & $188.45 * *$ & $480.70 * *$ & $3.68 * *$ \\
\hline Line * Tester effect & 48 & $30.70 * *$ & $59.03 * *$ & $0.0055 * *$ & $29.88 * *$ & $130.41 * *$ & $0.37 * *$ \\
\hline Environment $*$ Crosses & 124 & $9.36 * *$ & $16.47 * *$ & $0.0021 * *$ & 2.92 & $20.13 * *$ & 0.02 \\
\hline Environment* Line effect & 12 & $25.28 * *$ & $44.15 * *$ & 0.0030 & 2.19 & 17.51 & 0.03 \\
\hline Environment $*$ Tester effect & 16 & 10.01 & 15.98 & 0.0013 & 3.05 & $36.84 * *$ & 0.03 \\
\hline $\begin{array}{l}\text { Environment * Line * Tester } \\
\text { effect }\end{array}$ & 96 & $7.26 * *$ & $13.09 * *$ & $0.0021 * *$ & 2.98 & $17.67 * *$ & 0.02 \\
\hline Error & 186 & 5.03 & 3.94 & 0.0013 & 4.24 & 11.47 & 0.04 \\
\hline$\sigma^{2}$ gca & & 1.3672 & 3.5539 & 0.0004 & 3.8899 & 15.5283 & 0.0502 \\
\hline$\sigma^{2}$ sca & & 4.2777 & 9.181 & 0.0007 & 4.2736 & 19.8229 & 0.0549 \\
\hline$\sigma^{2}$ gca/ $\sigma^{2}$ sca & & 0.3196 & 0.39 & 0.57 & 0.9102 & 0.78 & 0.91 \\
\hline
\end{tabular}

***. Significant at $5 \%$ and $1 \%$ level respectively 
Table. 1 continued

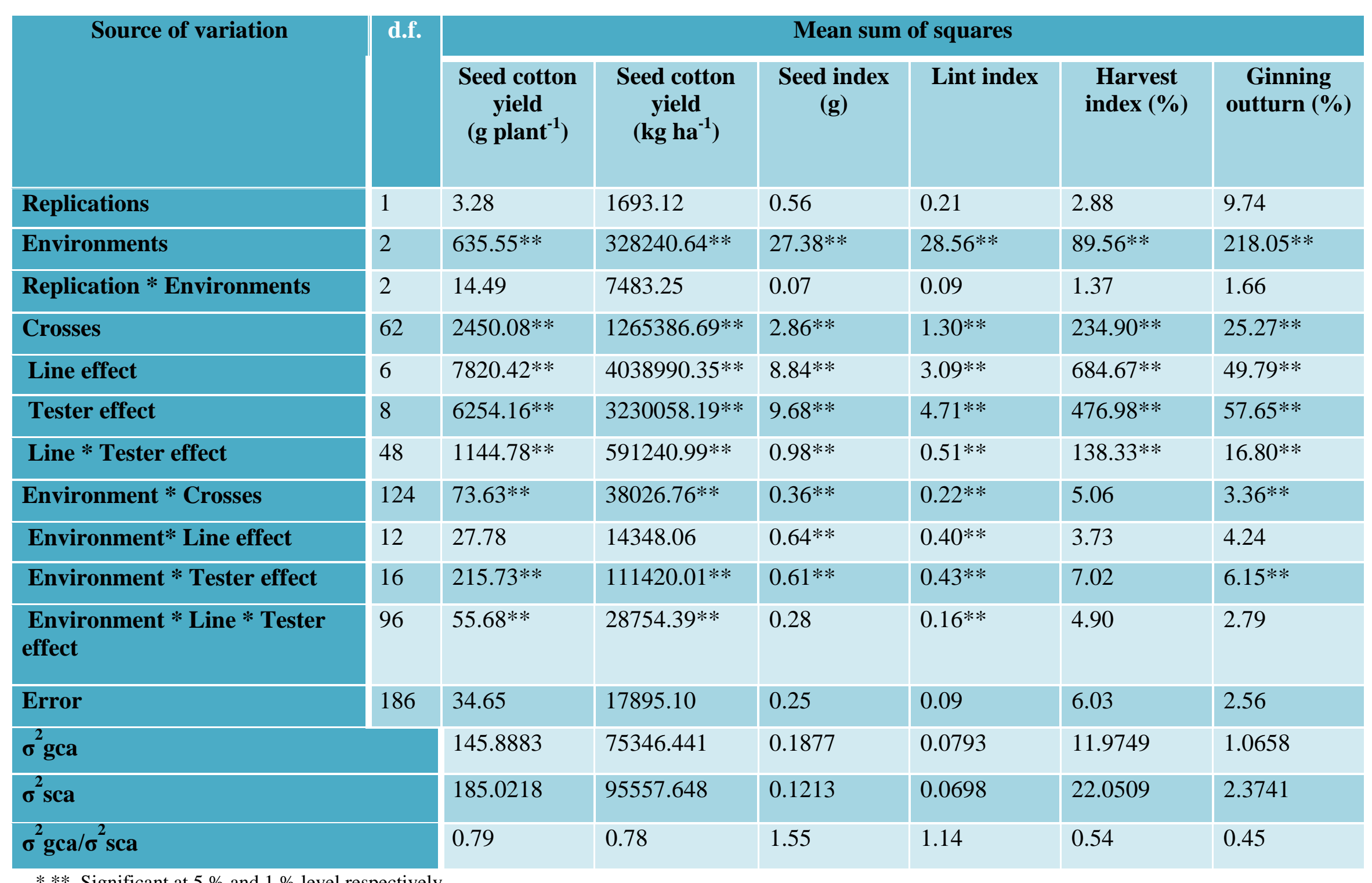


Table. 1 continued

\begin{tabular}{|c|c|c|c|c|c|}
\hline \multirow[t]{2}{*}{ Source of variation } & \multirow[t]{2}{*}{ d.f. } & \multicolumn{4}{|c|}{ Mean sum of squares } \\
\hline & & UHML (mm) & $\begin{array}{c}\text { Uniformity index } \\
(\%)\end{array}$ & $\begin{array}{c}\text { Micronaire } \\
\left(\mu \operatorname{inch}^{-1}\right)\end{array}$ & $\begin{array}{c}\text { Fibre strength } \\
\left(\mathrm{g} \mathrm{tex}^{-1}\right)\end{array}$ \\
\hline Replications & 1 & $15.48 * *$ & $20.68 * *$ & 0.001 & $15.48 * *$ \\
\hline Environments & 2 & $66.54 * *$ & $289.67 * *$ & $0.76^{* *}$ & $159.38 * *$ \\
\hline Replication * Environments & 2 & 0.57 & 0.50 & $0.06 * *$ & 0.57 \\
\hline Crosses & 62 & $9.51 * *$ & $23.75^{* *}$ & $1.20 * *$ & $21.61 * *$ \\
\hline Line effect & 6 & $40.82 * *$ & $85.04 * *$ & $2.20 *$ & $105.23^{* *}$ \\
\hline Tester effect & 8 & 9.87 & 17.33 & $2.53 * *$ & 9.03 \\
\hline Line * Tester effect & 48 & $5.53 * *$ & $17.16^{* *}$ & $0.86^{* *}$ & $13.25^{* *}$ \\
\hline Environment $*$ Crosses & 124 & 0.15 & $2.09 * *$ & 0.01 & 0.41 \\
\hline Environment* Line effect & 12 & 0.17 & 0.61 & 0.01 & 0.18 \\
\hline Environment $*$ Tester effect & 16 & 0.15 & $3.75^{* *}$ & 0.01 & $1.03 * *$ \\
\hline Environment $*$ Line $*$ Tester effect & 96 & 0.15 & $2.00 * *$ & 0.01 & 0.34 \\
\hline Error & 186 & 1.14 & 1.19 & 0.01 & 1.14 \\
\hline $6^{2}$ gca & & 0.5043 & 1.0415 & 0.0491 & 1.1666 \\
\hline $6^{2}$ sca & & 0.732 & 2.6615 & 0.1416 & 2.0184 \\
\hline $6^{2}$ gca $/ 6^{2}$ sca & & 0.69 & 0.39 & 0.35 & 0.58 \\
\hline
\end{tabular}

*,**. Significant at $5 \%$ and $1 \%$ level respectively 
Table.2 Mean, Minimum and Maximum of Hybrid Performance, Better parent Value, Heterobeltiosis, SCA, GCA of 63 Hybrids and their 16 Parents in cotton across three locations

\begin{tabular}{|c|c|c|c|c|}
\hline & & \multicolumn{3}{|c|}{$\begin{array}{l}\text { Performance of highest and lowest performing genotypes } \\
\text { at different environment }\end{array}$} \\
\hline & Seed cotton yield g plant ${ }^{-1}$ & \multicolumn{3}{|c|}{ SCA (Crosses) } \\
\hline Hybrid performance & Pooled & E1 & E2 & E3 \\
\hline Minimum & 26.35 & $-31.36 * *$ & $-21.89 * *$ & $-24.81 * *$ \\
\hline Maximum & 115.33 & $26.87 * *$ & $39.95 * *$ & $36.52 * *$ \\
\hline \multirow[t]{2}{*}{ Mean } & 51.31 & & & \\
\hline & & \multicolumn{3}{|c|}{ GCA (Parent) } \\
\hline Better parent value & Pooled & E1 & E2 & E3 \\
\hline Minimum & 29.38 & $-18.82 * *$ & $-17.16 * *$ & $-14.83 * *$ \\
\hline Maximum & 49.05 & $22.89 * *$ & $20.43 * *$ & $20.58 * *$ \\
\hline \multirow[t]{2}{*}{ Mean } & 42.52 & & & \\
\hline & & \multicolumn{3}{|c|}{ Heterobeltiosis (\%) } \\
\hline Heterobeltiosis & Pooled & E1 & E2 & E3 \\
\hline Minimum & $-36.90 * *$ & $-49.17 * *$ & $-29.11 * *$ & $-31.30 * *$ \\
\hline Maximum & $135.11 * *$ & $126.13 * *$ & $137.12 * *$ & $143.22 * *$ \\
\hline
\end{tabular}

*** Significant at $5 \%$ and $1 \%$ level respectively

Fig.1 Relation of heterobeltiosis and mean seed cotton yield in top performing cross DHY-286-1 x NH-635

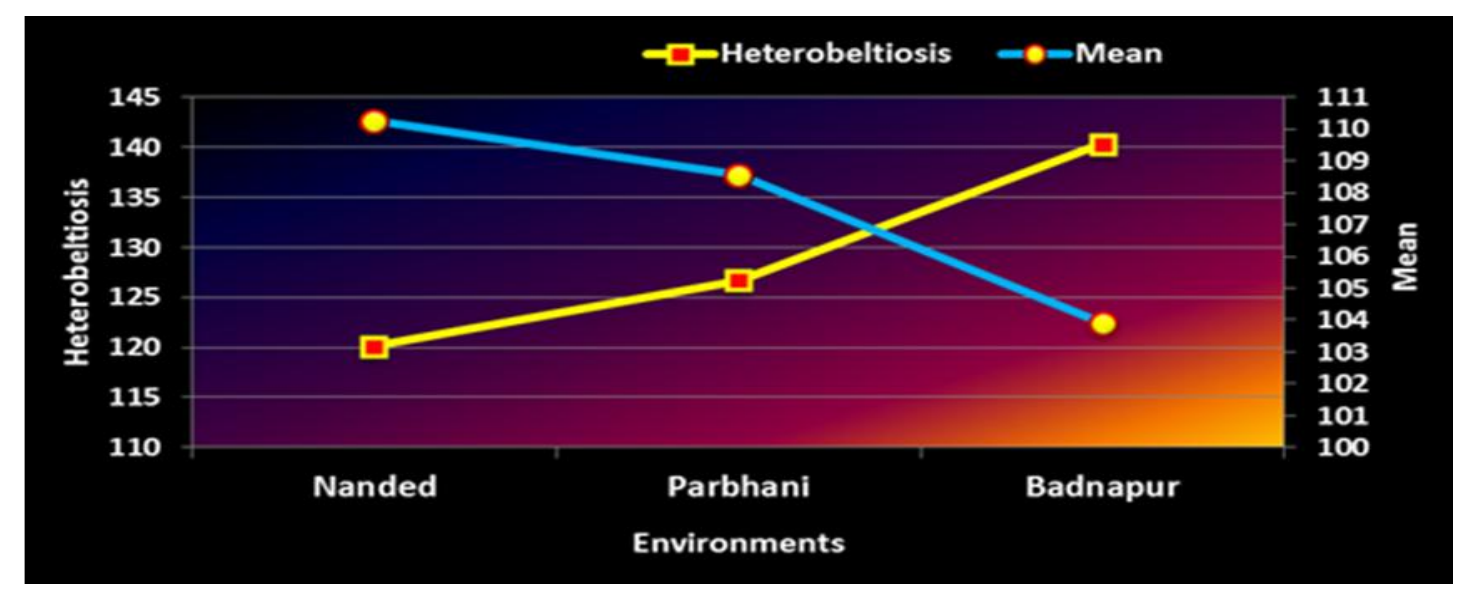


Fig. 2 Combining ability estimates of promising parents and crosses for seed cotton yield plant ${ }^{-1}$ (Figure 2A: GCA effects of promising parents; Figure 52: SCA effects of promising crosses)
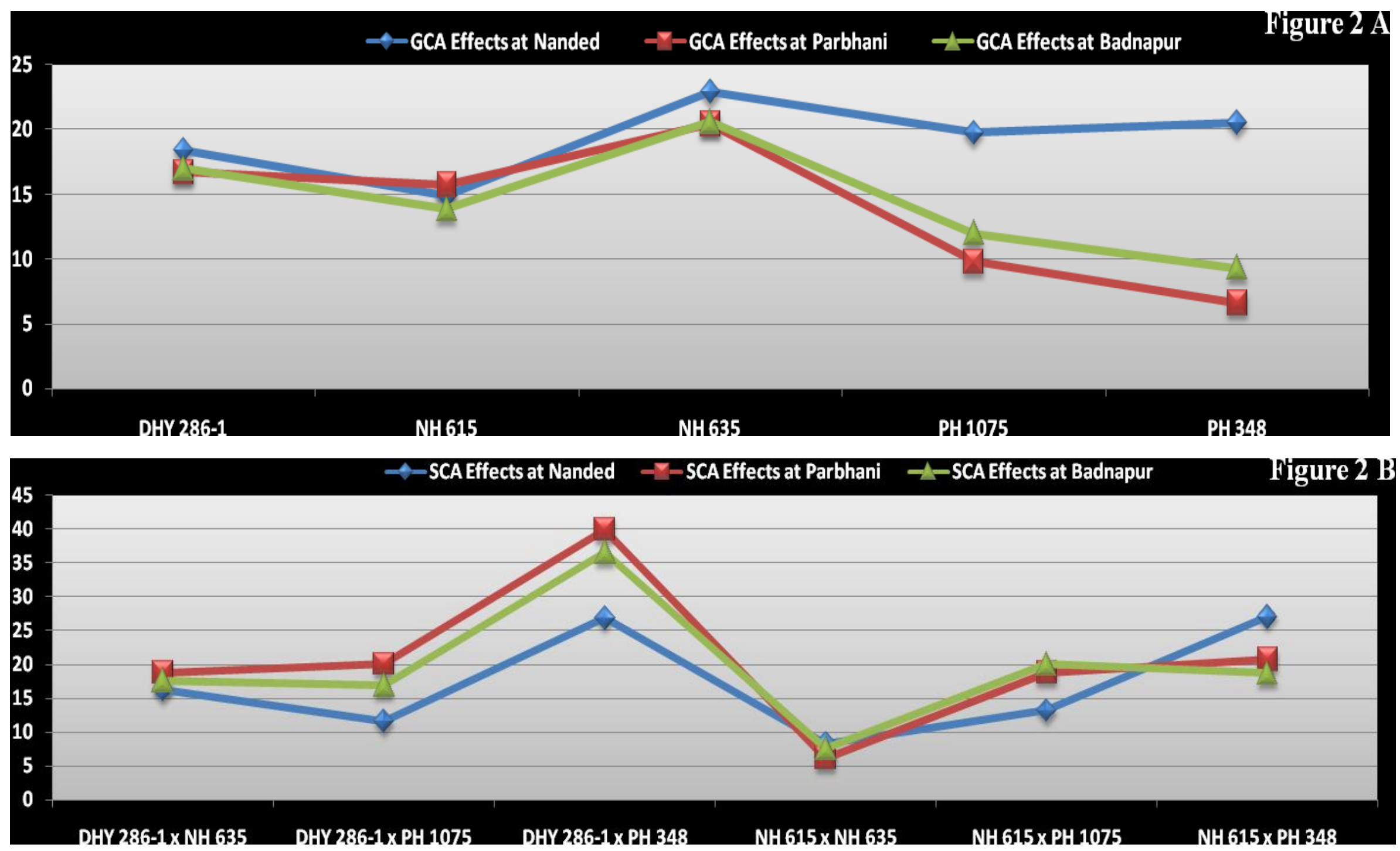
The GCA of parents was higher at $E_{1}$ than $E_{2}$ and $E_{3}$ indicating the role of environment in interacting with genotype to alter the stability of gene action. The SCA of top performing crosses was higher at $E_{2}$ and $E_{3}$ than $E_{1}$ indicating the more stable nature of crosses in low yielding environment as compared to parents which is evident from high SCA and high heterobeltiosis at low yielding environment than high yielding environments. The pooled and environment wise maximum and minimum values of seed cotton yield of parents and crosses for mean, GCA, heterobeltiosis and SCA are presented in table 2 .

Higher heterobeltiosis and higher SCA of crosses at low yielding environment indicate that the stability of heterozygous genotypes was more than homozygous genotypes which is presented in Fig. 1 and 2 which were aroused out of individual buffering of heterozygous nature of crosses (Cole et al., 2009). The results also indicates that there is positive relation between heterobeltiosis and SCA as faster growing hybrid population could take full advantage of favorable environmental conditions early in the season and better tolerate unfavorable conditions (drought, insects) occurring later in the season. This could result in increased yields and stability relative to the inbreds. The opposite of this would occur under favorable environmental conditions where any advantage associated with increased rate of growth would be negated by inbred genotypes exploiting a full season of favorable conditions (Went, 1953).

Combining ability for the pooled data across environments for all the traits indicated the importance of both additive and non-additive gene effects. The mean square for environments was highly significant for seed-cotton yield, indicating that the environments were much diverse to influence the yield and yield component traits. High magnitude of significance was observed for testers and SCA with environments in the combined analysis for seed-cotton yield. This suggests that trait performances of parents and hybrids were altered by the environmental conditions, which infers that none of the parents or hybrid combinations was stable across environments but the yield of heterozygotes was comparatively less hampered than homozygotes in low yielding environment.

Thus, the non-additive effects and environmental effects were more important than additive effects for seed cotton yield. Further selection for these traits should be based upon evaluation in several environments. The ratio of GCA and SCA mean square components was less than unity for most of the traits except plant height, boll weight, seed index, lint index and monopodia. This suggested that genetic variation was predominately of non-additive type. Similar findings were also reported by Anandan (2010).

Selection of parents for hybrid breeding based on GCA effects alone has limited value. Therefore, selection of the parental lines on the basis of GCA effects in conjugation with per se performance would be of great value. DHY 286-1 and NH 615 from lines and NH 635, PH 1075 and PH 348 from testers appeared to be the best general combines for seed cotton yield and some fibre properties which may do well in cross combination with other parents.

These parents along with high GCA also possessed high per se for yield in addition to that NH 615 and NH 635 also found promising for fibre quality. Selection of the most encouraging cross combination needs high SCA along with high per se and GCA effects of respective parents. The cross combination DHY 286-1 X PH 348, DHY 286-1 X NH 635, DHY 286-1 X PH 1075, NH 615 X PH 348, NH 615 $\mathrm{X}$ PH 1075 were found significantly positive for SCA effects with high mean for seed cotton yield. Cross NH 615 X NH 635 also exhibited high mean along with significantly positive SCA for yield. Crosses having high per se, auspicious SCA, and at least one parent with competent combiner would likely to increase the concentration of advantageous alleles (Marilia et al., 2001). 
Environment influence gene action so genotypes should be tested at several environments to know precise magnitude of combining ability.

Heterozygosity and homozygosity also affects the combining ability across the locations due to their differential response to environment. In order to harvest higher yield in stressful environments and cultivation in broad areas, hybrids were found more promising than parents as the most of parents used in this programme were released varieties. The future study would be important to conduct these experiments over several environments that include diverse environmental conditions.

\section{Declaration}

The authors declare no conflict of interest.

\section{Acknowledgement}

Amol E. Patil acknowledges the INSPIRE fellowship granted by Department of Science and Technology, Government of India for carrying out his Ph.D. research.

\section{References}

Anandan, A. 2010. Environmental impact on the combining ability of fiber traits and seed cotton yield in cotton. J. Crop Improv., 24(4): 310-323.

Cole, C.B., Bowman D.T., Bourland F.M., Caldwell W.D., Campbell B.T., Fraser D.E., and Weaver, D.B. 2009. Impact of heterozygosity and heterogeneity on cotton lint yield stability. Crop Sci., 49:1577-1585.

Dwivedi, D.K., Pandey M.P., Pandey S.K., and Rongbai L.I., 1999. Combining ability over environments in rice involving indica and tropical japonica lines. Oryza36:101-107.

Eli-itriby, H.A, Selim A.R., and Shehata A.H. 1981. Genotype $\times$ environments interaction from combining ability estimates in maize (Zea mays L.). Egypt J. Genet Cytol.10:175-186.

Kempthorne, O., 1957. An introduction to genetic statistics. New York: John Wiley $\&$ Sons.

Marilia, C.F., Servio T.C., Valter O.R., Clibas V., and Sui T.M., 2001. Combining ability for nodulation in common bean (Phaseolus vulgaris L.) genotypes from Andean and Middle American gene pools. Euphytica, 118: 265-270.

Perkins, H.D., Ethridge D.E., and Bragg C.K., 1984. Fiber. In Cotton Agronomy Monograph No. 24, Eds. R.J. Kohel and C.F. Lewis, 438 - 465. Madison, WI: ASA, CSSA and SSSA.

Rashmi R., Singh V.P. Singh U.S., Singh R.K., and Khush G.S. 2000. Crop husbandry and environmental factors affecting aroma and other quality traits. In Aromatic rices, Eds. R.K. Singh, U.S. Singh, and G.S. Khush, 201-216. New Delhi, India: Oxford and IBH.

Went, F.W. 1953. Gene action in relation to growth and development: I. Phenotypic variability. Proc. Natl. Acad. Sci. USA, 39: 839-848.

\section{How to cite this article:}

Patil, A.E., D.B. Deosarkar and Puttawar, M.R. 2018. Environmental Impact on the Stability of Gene Action for Seed Cotton Yield in Cotton (Gossypium hirsutum L.). Int.J.Curr.Microbiol.App.Sci. 7(01): 1319-1329. doi: https://doi.org/10.20546/ijcmas.2018.701.161 